\title{
Ultrastructural study of two patterns in the interaction of Helicobacter pylori with neutrophils
}

\author{
H Rautelin, C-H von Bonsdorff, B Blomberg, D Danielsson
}

\begin{abstract}
As evidenced by electron microscopy, unopsonised bacteria of some Helicobacter pylori strains were readily taken into cytoplasmic vacuoles of human neutrophils; those of other strains were only rarely absorbed. The strains engulfed like this also induced strong oxidative burst reactions in neutrophils, as measured by chemiluminescence. This has been associated with peptic ulcer disease, in the past. The ultrastructural interaction patterns agreed with the reaction patterns shown by chemiluminescence.
\end{abstract}

(F Clin Pathol 1994;47:667-669)

The causal association between Helicobacter pylori infection and active chronic gastritis, ${ }^{12}$ and its association with peptic ulcer disease ${ }^{3}$ have been confirmed. The exact pathogenetic mechanisms are still not known. In the attendant gastric inflammation is almost invariably an infiltration of the mucosal wall by polymorphonuclear leucocytes, lymphocytes, and monocytes. We have recently shown that unopsonised organisms of some strains of $H$ pylori rapidly adhere to human neutrophils in vitro, resulting in visible agglutination. These also induced a rapid and strong oxidative burst in polymorphonuclear leucocytes, as measured by chemiluminescence. ${ }^{4}$ Such strains occurred significantly more often in patients with peptic ulcers than in patients with gastritis alone. The aim of this study was to discover whether unopsonised $H$ pylori organisms could be phagocytosed by polymorphonuclear leucocytes and, if so, whether this was concordant with the reaction pattern in chemiluminescence.

\section{Methods}

Four $H$ pylori strains were used in the experiments: reference strain NCTC 11637, which, unopsonised, adheres rapidly to neutrophils and induces a rapid and strong oxidative burst in chemiluminescence; a Canadian strain designated C 7050 with low adherence and oxidative burst rates; and two additional strains isolated from gastric biopsy specimens of patients at our hospital. One of the clinical isolates $(\mathrm{O} 30 / 90)$ induced a strong oxidative burst in polymorphonuclear leucocytes, as measured by chemiluminescence, and the other strain $(\mathrm{O} 1 / 90)$ gave a slow and weak chemiluminescence pattern. The reactions of the two types of strains were studied in parallel and always with the same set of polymorphonuclear leucocytes.

The strains were stored at $-70^{\circ} \mathrm{C}$ before use and for experiments were grown on GC agar plates (GC agar base, BBL, Cockeysville, Maryland, USA, supplemented with $1 \%$ bovine haemoglobin (BBL), $10 \%$ horse serum, and $1 \%$ IsoVitalex) without antibiotics.

Blood anticoagulated with heparin was obtained from four members of staff who did not have raised $H$ pylori antibody titres by enzyme immunoassay. ${ }^{5}$ Blood from a single donor was used for each series of experiments on a particular day. To obtain polymorphonuclear leucocytes the method of Böyum was used with minor modifications. ${ }^{6}$

Live bacteria $\left(10^{8} / \mathrm{ml}\right)$ and polymorphonuclear leucocytes $\left(2 \times 10^{6} / \mathrm{ml}\right)$ in phosphate buffered saline (same proportions as in chemiluminescence) were incubated on a roller at $37^{\circ} \mathrm{C}$ and aliquots for electron microscopy were removed at different time intervals. Samples were fixed by adding an equal volume of $5 \%$ glutaraldehyde (EMS, Fort Washington, Pennsylvania, USA) in $0.1 \mathrm{~N}$ sodium cacodylate and the fixation was allowed to continue for at least one hour. The fixative was then exchanged to cacodylate buffer with $0.2 \mathrm{M}$ sucrose until further processing. Postfixation was performed with $1 \%$ osmium tetroxide in cacodylate buffer for one hour at room temperature, and stained en bloc in $1 \%$ uranyl acetate over night. Dehydration was done through ethanol series and the pellets were embedded in LX-112 (Ladd Research Ind, Burlington, Vermont, USA) after propylene oxide incubations. Thin sections were cut with a diamond knife and the sections were poststained with lead hydroxide. Electron micrographs were taken with a Jeol 100 CX II microscope.

\section{Results}

Mixing bacteria of the strains NCTC 11637 or O 30/90 with polymorphonuclear leucocytes resulted in an immediate attachment of the bacteria to the cells. After one minute of incubation, typically, many bacteria adhered to the plasma membrane (fig 1). The attachment to the plasma membrane is characterised by a very regular apposition about 5 $\mathrm{nm}$ away from the two membranes (fig $2 \mathrm{~A}$ ), but the cytoplasm underneath the attachment site does not show any morphological changes in contrast to the findings with some invasive bacteria. ${ }^{7}$ Intracellular bacteria were found in 


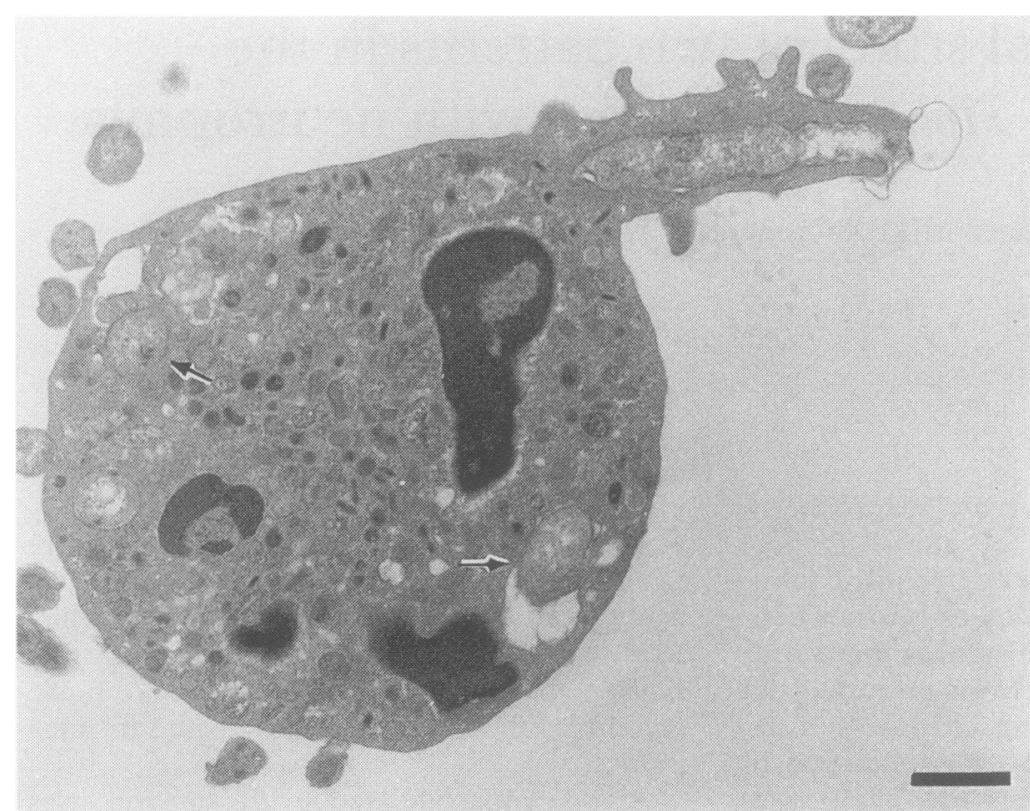

Figure 1 Electron micrograph of a polymorphonuclear cell after one minute of incubation with the NCTC 11637 strain of $H$ pylori. In addition to the one bacterium in the process of being engulfed, there are a few bacteria already located in apparent cytoplasmic vacuoles (arrows). Bar $=1.0 \mu \mathrm{m}$.

vacuoles rather tightly surrounding the bacterium. In successive samples an increasing number of internalised bacteria were seen (fig 2B). In some instances the vacuoles became larger, lysosome-like, and seemed to contain not only remnants of bacteria but also mor-
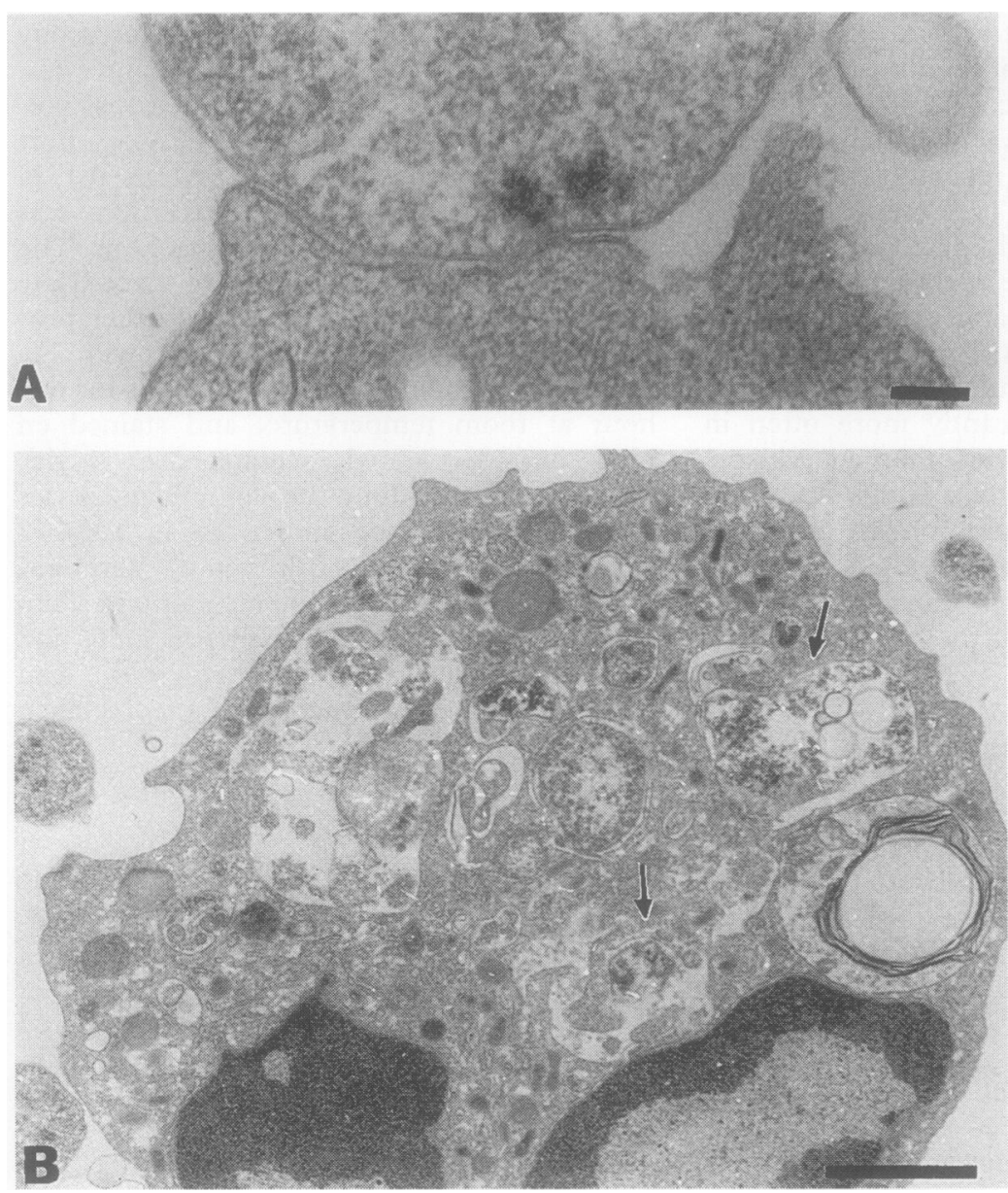

Figure 2 Interaction of the clinical isolate $O 30 / 90$ of $H$ pylori with human polymorphonuclear leucocytes. Incubation was for five minutes. (A). Detail of the contact between the bacterium (above) and the plasma membrane. Note the uniform distance between the two membranes. No discernible changes in the cytoplasmic structures at the attachment site are observed. Bar $=100 \mathrm{~nm}$. (B). Numerous intracellular bacteria, some of which seem to be disintegrating in lysosome-like structures (arrows). Bar $=1.0 \mu \mathrm{m}$. phologically intact bacteria. In samples incubated for up to one hour there were still many intact-looking bacteria inside cellular vacuoles. In no instance were organisms found in the free cytoplasm - that is, without a surrounding cellular membrane.

In contrast, the strains $C 7050$ and $O 1 / 90$ did not show any particular tendency to attach to the cells, not even after prolonged incubation for up to one hour. Only occasionally were bacteria seen attached to the cells, and intracellular organisms were only rarely found.

\section{Discussion}

Bernatowska et al ${ }^{8}$ have shown $H$ pylori within phagocytic vacuoles of neutrophils in the presence of complement. Recently Andersen et $a l^{9}$ reported that $H$ pylori was also phagocytosed without the presence of opsonins, but those experiments were mainly performed with a single strain. In the present study two different patterns in the interaction of $H$ pylori with polymorphonuclear leucocytes have been shown. The rapid ingestion of the organisms of the strains NCTC 11637 and O 30/90 reflected our previous findings of the ability of these strains to induce a rapid oxidative burst in polymorphonuclear leucocytes, as measured by luminol-enhanced chemiluminescence. ${ }^{4}$ The peak values in chemiluminescence were obtained within five to 15 minutes, ${ }^{4}$ thus coinciding with the phagocytosis verified by electron microscopy in this study.

Some of the bacteria of the NCTC 11637 and $O 30 / 90$ strains found in the phagocytic vacuoles after 60 minutes of incubation were coccoidal in form, and in some instances obviously destroyed. Our recent study did not show any phagocytic killing of $H$ pylori in polymorphonuclear leucocytes unless complement was added. However, further studies are needed to clarify if the ingested NCTC 11637 type of bacteria can survive in polymorphonuclear leucocytes. The ingested bacteria in this study were never found free in cytoplasm and thus the internalisation observed here does not resemble the one described for invasive bacteria, such as Listeria or some Shigella strains. $^{7}$

A typical feature for $H$ pylori infection in the gastric mucosa is an abundant infiltrate of polymorphonuclear leucocytes. We have described a novel heat-labile activity, present in those $H$ pylori strains like NCTC 11637 and $O$ 30/90, which shows rapid and strong oxidative burst reactions in neutrophils, as measured by chemiluminescence. Reactive oxygen metabolites, such as superoxide radicals $\left(\mathrm{O}_{2}^{-\cdot}\right)$, hydrogen peroxide $\left(\mathrm{H}_{2} \mathrm{O}_{2}\right)$, and hydroxyl radicals $\left({ }^{\circ} \mathrm{OH}\right)$ can depolymerise gastric mucin, ${ }^{10}$ and moreover, such radicals are strongly toxic to various types of tissue cells. When $H$ pylori organisms penetrate the mucus layer they may meet and challenge neutrophils and $H$ pylori cells of the NCTC 11637 type might then induce oxidative bursts in the neutrophils. It is tempting to speculate that the rapid liberation of reactive 
metabolites might act both by changing viscoelastic properties of the mucin (thus facilitating penetration?) and by causing tissue injuries, and thus paving the way for peptic ulcer disease.

This work was partly supported by the Research Committee of Örebro County Council and the Örebro Medical Center Research Foundation. We thank $M$ Jurstrand and $A$ Mörttinen for their excellent technical help.

This work was presented in part at the VI European Workshop on Gastroduodenal Pathology and Helicobacter pylori (Acta Gastroenterologica Belgica 1993;56 (Suppl):119 (Abstract))

1 Marshall BJ, Armstrong JA, McGechie DB, Glancy RJ. Attempt to fulfill Koch's postulates for pyloric campylobacter. Med F Aust 1985;142:436-43.

2 Morris A, Nicholson G. Ingestion of Campylobacter pyloridis causes gastritis and raised fasting gastric $\mathrm{pH}$. Am 7 Gastroenterol 1987;82:192-9.

3 Rauws EAJ, Tytgat GNJ. Cure of duodenal ulcer associ- ated with eradication of Helicobacter pylori. Lancet $1990 ; 335: 1233-5$

4 Rautelin H, Blomberg B, Fredlund H, Järnerot G, Danielsson D. Incidence of Helicobacter pylori strains activating neutrophils in patients with peptic ulcer disease. Gut 1993;34:599-603.

5 Kosunen TU, Höök J, Rautelin HI, Myllylä G. Agedependent increase of Campylobacter pylori antibodies in blood donors. Scand $\mathcal{F}$ Gastroenterol 1989;24:110-4.

6 Fredlund H, Olcen P, Danielsson D. A reference procedure to study chemiluminescence induced in polymorphonuclear leukocytes by Neisseria meningitidis. phonuclear leukocytes

7 High N, Mounier J, Prévost MC, Sansonetti PJ. IpaB of Shigella flexneri causes entry into epithelial cells and Shigella flexneri causes entry into epithelial cells and escape f

8 Bernatowska E, Jose P, Davies H, Stephenson M, Webster D. Interaction of Campylobacter species with antibody, complement and phagocytes. Gut 1989;30:906-11.

9 Andersen LP, Blom J, Nielsen $H$. Survival and ultrastructural changes of Helicobacter pylori after phagocytosis by human polymorphonuclear leukocytes and monocytes. APMIS 1993;101:61-72.

10 Grisham MB, von Ritter C, Smith BF, Lamont JT, Granger DN. Interaction between oxygen radicals and gastrin mucin. Am f Physiol 1987;253:G93-6.

\title{
IgD multiple myeloma with thoracic spine compression due to epidural extra-osseous tumour spread
}

\author{
Y I Lolin, C W Lam, W H Lo, K L Au, J R L Masarei
}

\begin{abstract}
On initial presentation of a patient with IgD multiple myeloma there were no features to suggest an unusual variant. Two months later she developed spinal cord compression due to an IgD plasmacytoma. This complication of IgD myeloma has rarely been reported. During the course of the disease and using the routine laboratory protocol for investigating and identifying paraproteins, including IgD, the patient's results became indistinguishable from those in Bence-Jones proteinuria myeloma.
\end{abstract}

\section{$(\mathcal{F}$ Clin Pathol 1994;47:669-671)}

Department of

Chemical Pathology,

Prince of Wales

Hospital, Chinese

University of Hong

Kong, Shatin, NT,

Hong Kong

Y I Lolin

J R L Masarei

Department of

Pathology, Princess

Margaret Hospital,

Princess Margaret

Road, Lai Chi Kok,

Hong Kong

C W Lam

W H Lo

$\mathrm{K} \mathrm{L} \mathrm{Au}$

Correspondence to:

Dr Y I Lolin

Accepted for publication

11 January 1994
IgD myeloma is rare. ${ }^{1-4}$ It generally follows a shorter course than other forms of myeloma, with more frequent extra-osseous spread, renal insufficiency, Bence-Jones proteinuria and atypical presentations and complications. ${ }^{1-3}$ The paraprotein band is also often either not visible or faint and diffuse. ${ }^{145}$ This, in conjunction with the usual large excess of Bence-Jones protein in the urine, can lead to a misdiagnosis of a Bence-Jones proteinuria myeloma. ${ }^{6}$

We report, as far as we are aware, the first documented case of IgD multiple myeloma in a Hong Kong Chinese patient. Although initially there were no distinctive features to suggest a rarer myeloma, she later developed thoracic spinal cord compression due to a soft tissue plasmacytoma. This particular complication is rare with IgD myelomas: our case seems to be only the second one described in the English language. ${ }^{7}$

\section{Case report}

A 55 year old Chinese woman presented with spontaneous low back pain. She had also had an episode of back pain one month earlier after a fall. Physical examination showed that she was pale, with muscle spasm over the lower back and local tenderness over the L5 vertebra, but was otherwise unremarkable. Investigations showed a haemoglobin of 103 $\mathrm{g} / \mathrm{l}$, normochromic normocytic anaemia, an erythrocyte sedimentation rate of $60 \mathrm{~mm} /$ first hour, white cells of $5 \times 10^{9} / 1$ (with a normal differential count) and a platelet count of $171 \times 10^{9} / 1$. The serum renal and liver function tests all yielded normal results. Serum total protein was $75 \mathrm{~g} / \mathrm{l}$, albumin $52 \mathrm{~g} / \mathrm{l}$, and the albumin adjusted calcium $2.33 \mathrm{mmol} / 1 . X$ ray pictures of the lumbar spine showed a collapsed L5 vertebra. Skull $x$ ray pictures showed multiple osteolytic lesions and a trephine bone marrow biopsy specimen of the iliac crest showed $95 \%$ plasma cells. The serum IgA was $0.5 \mathrm{~g} / 1$ (range $1 \cdot 25-4 \cdot 26$ ), IgG $7 \cdot 18 \mathrm{~g} / 1$ (range $7 \cdot 90-17 \cdot 90$ ), and $\operatorname{IgM} 0 \cdot 27 \mathrm{~g} / 1$ (range $0.63-3.07 \mathrm{~g} / \mathrm{l}$ ). Serum protein electrophoresis (agarose gels; Beckman Paragon SPE kit) showed a small, discrete paraprotein band of $4 \mathrm{~g} / 1$ in the mid $\beta / \gamma$ region (figure). Urine contained $0.9 \mathrm{~g} / 1$ of protein and a faint 